\title{
CONFUSION OF EDUCATOR POLICY IN MINISTRY OF RELIGIOUS AFFAIRS 1945-2016
}

\author{
Muh. Saerozi \\ Fakultas Tarbiyah dan Ilmu Keguruan IAIN Salatiga \\ J1. Tentara Pelajar 02 Salatiga, 50721 \\ e-mail: saerozi2010@yahoo.com
}

\begin{abstract}
This essay examines the dynamics of the development of educator policy at the Ministry of Religious Affairs, which begins with the educator concept in Education Law at the Ministry of Religious Affairs from 1945 to 2016, and what the philosophical meaning of the development of the concept is. It also uncover where the confusion of the concept of educators throughout the history. This essay concludes with the conceptual solutions to educator problems enshrined in the Educational Law. The author finds there is a change of educators' concept on every amendment to Education law, each of which contains a specific philosophical meaning. The concept of educator that has been changed still entails the some problems up to the present time. The confusion of the concept in the law affects the regulation of educators in the Ministry of Religious Affairs, and thus it needs to be revised and finds alternative solution as offered in this paper.
\end{abstract}

\begin{abstract}
Abstrak: Kerancuan Kebijakan Pendidik di Kementerian Agama 19452016. Esai ini mengkaji dinamika perkembangan kebijakan pendidik pada Kementerian Agama, yang diawali dengan konsep pendidik dalam undang-undang pendidikan dan peraturan Menteri Agama sejak tahun 1945 sampai 2016, dan apa makna filosofis dari perkembangan konsep tersebut. Selanjutnya diungkap dimana letak kerancuan konsep pendidik dalam sepanjang sejarah tersebut. Pada bagian akhir difokuskan untuk menemukan solusi konseptual terhadap problem pendidik yang terdapat dalam undang-undang pendidikan. Penulis menemukan ada perubahan konsep pendidik pada setiap perubahan undang-undang pendidikan, yang memuat makna filosofis yang spesifik. Konsep pendidik yang telah diubah masih menyisakan masalah sampai sekarang. Kerancuan konsep dalam undang-undang berdampak pada peraturan pendidik di Kementerian Agama, sehingga perlu dilakukan revisi sebagaimana alternatif yang ditawarkan dalam tulisan ini.
\end{abstract}

Keywords : education, Religious Affairs Ministry, policy, teacher, educational support personnel 
Muh. Saerozi: Confusion of Educator Policy in Ministry of Religious Affairs 1945-2016

\section{Introduction}

Educator Policy under the Ministry of Religious Affairs employs the Act of the Republic Indonesia No. 20 Year 2003 on National Education System as the guideline. This law has often been criticized. For example, the Constitutional Court Hearing has ever conducted material assessment towards its article. ${ }^{1}$ People criticized not only on the articles of the laws dealing with funding, facilities and equipment, and curriculum, but also, they criticized the article discussing about educators. ${ }^{2}$

There often exist critics and complaints from the people towards the Act of National Education System; it seems that there should be reforms on this Act. Nowadays, the act of National Education System has been amended twice. The current Act implemented in the educational system in Indonesia is the result of amendments from the Act No. 2 Year 1989 on National Education System. ${ }^{3}$ While the Act No. 2 Year 1989 is the result of amendments from the Act No. 4 Year 1950 job the Act No. 12 Year 1954. ${ }^{4}$

When the signal of reforms appears in the community, then, the Islamic academician should morally propose several alternative scientific concepts. This is because the content of the Act will mainly influence the Islamic education policy in the Ministry of Religious Affairs.

The proposed concepts for the reforms of the Act should not be merely a general theoretical framework. But it also needs to look at the redaction and diction of every chapter, article and verse. The implementation of education policy in any levels should really consider the redaction and diction of the chapters, articles and verses. This is because any scientific argumentations in literature and the law practices also look at the redaction and diction.

Redaction and diction are also considered highly in the previous education acts. Therefore, to achieve the aims of this study, it is important to comparatively analyse the content of the Act No. 20 Year 2003 and the previous acts on Education systems implemented in Indonesia. To sharpen this comparative analysis, it is necessary to include the regulations of the minister of Religious Affairs as the data. In addition, to come to comprehensive conclusion, it is also important to consider several historical occurrences happened during the implementation of the acts. This is because the redaction and diction of an article in the act should consider the historical context. Understanding the historical concept, according to Nasution, is important to clarify the nowadays understanding. The education policy implemented in Indonesia

${ }^{1}$ Editorial board, "Pengantar Redaksi," in Jurnal Konstitusi, Vol. 3, No, 2006, p. 5.

${ }^{2}$ See in Himpaudi, "Masalah Dikotomi PAUD \& Dampaknya terhadap Mutu dan Kesehteraan Pendidik PAUD Non Formal serta Usulan Perubahan Undang-Undang," in https://www.change. $\mathrm{org} / \mathrm{p} /$ mahkamah-konstitusi-ubah-undang-undang-sisdiknas-serta-undang-undang-guru-dandosen-terkait-paud/u/13559697, accessed on December 28, 2016.

${ }^{3}$ Editorial Team of Wacana Intelektual, Guru dan Dosen \& Sisdiknas (NP: WI Press, 2006), p. 55.

${ }^{4}$ Editorial Team of Tugu Muda, Undang-Undang Republik Indonesia Nomor 2 tahun 1989: Sistem Pendidikan Nasional (Semarang: Tugu Muda, 1989), p. 17. 
today is the result of the development of education policy which grew during the national history in the past. ${ }^{5}$

\section{Problem Statement}

This paper is not the first paper discussing the problems within the education policy in the Ministry of Religious Affairs and the National Policy of Education in Indonesia. There are previous papers. However, I still can argue that this paper offers contribution with regards to the discourse. The previous papers analyses the issue from different aspects. For example, Djohar has written about the analysis of the national policy on education system from the perspective of education practices and budget. The paper analyses the verdict of the Constitution Court on the Act of National Education System from the aspect of budget. ${ }^{6}$

Another paper was written by Moh Shohib entitled Re-establishing Education as Human Rights focuses on education as the right inherent to every human being. ${ }^{7}$ In the same year, Ali Riyadi writes about monetary policy of Islamic education. ${ }^{8}$

Compared to those previous papers, there are at least four different aspects in this paper. The first one is that the discussion focuses on the educator policy. The second difference is that the data used are mainly from the content of the Acts and the Minister of Religious Affairs regulations. In this sense, it can be said that this paper is a policy review essay. The third one is that in order to understand the issue, the paper applies historical approach. And, finally, the fourth difference is that it proposes alternative revision of concepts.

The first section of this paper is to discuss about how is the development of educator concept in the Act of National Education System and the Minister of Religious Affairs regulation from 1945 up to now? What is the philosophical meaning of the development of the concept? And in the next section, this paper demonstrates the confusion of the educator concept during those periods. Finally, this paper focuses to find out the conceptual solution for the educator problems exist in the Act of National Education System. Theoretically, the revised concept in the Law should give positive impact to the educator regulation in the Ministry of Religious Affairs.

\section{Methodology}

The discussion in this paper employs historical approach because the questions above

${ }^{5}$ S. Nasution, Sejarah Pendidikan Indonesia (Jakarta: Bumi Aksara, 1994), p. v.

${ }^{6}$ Djohar, "Analisis Undang-undang Sisdiknas Ditinjau dari Segi Praksis Pendidikan dan Anggaran Pendidikan," in Jurnal Konstitusi, Vol. 3, No. 1, 2006, p. 13-34.

${ }^{7}$ Moh. Shohib, 'Mengembalikan Pendidikan sebagai Hak Asasi Manusia," in Jurnal Konstitusi, Vol.3, No. 1, 2006, p. 35-54.

${ }^{8}$ Ali Riyadi, Politik Pendidikan: Menggugat Birokrasi Pendidikan Nasional (Yogyakarta: ArRuzz Media, 2006), p. 77-80. 
contain the element of time. ${ }^{9}$ Moreover, the context covers the time range between the years of 1945 until 2016.

The primary sources in the discussion include the Act No. 4 Year 1950, the Act No. 12 Year 1954, the Act No. 22 Year 1961, the Act No. 2 Year 1989, the Act No. 20 Year 2003, government regulations, the minister of religious Affairs regulations, Indonesian dictionary, and educational encyclopaedia, Dutch-Indonesian dictionary, and old Javanese dictionary. Meanwhile, the secondary data are taken from books and articles that discussed about educational policy and the Islamic education policy in Indonesia.

The analysis of this study focuses on observing the changes and differences between Acts and the inconsistency in Acts. Besides that, this analysis also discusses primarily to see the changes exist in the Minister of Religious Affairs regulations. The discussion of this study basically answers the questions proposed that have been explained above. Finally, the answers of the questions in this study are proposed as the alternative solutions as stated in the conclusions.

\section{The Development of the Usage of Terms Teacher and Lecturer}

The Act No. 4 Year 1950 and The Act No. 12 Year 1954 use the term teacher. The selection of this term is appropriate within the scope of the Act in formal education. Based on Old Javanese Dictionary, the term teacher in Indonesia 'guru' is derived from Sanskrit language which means a venerable person. The other meaning of the term is spiritual advisor. ${ }^{10}$ The term lecturer applied in recent era actually was not mentioned in both the Act No 4 Year 1950 and No. 12 Year 1954. The Presidential Regulation No. 11 Year 1960 on the Establishment of State Institute for Islamic Studies does not discuss any terms for lecturer. It is in the Act No. 22 Year 1961 regarding higher education that we can find the term lecturer. This Act employs the term teaching staff. In this regard, it is worth mentioning that there are permanent and associate teaching staffs. ${ }^{11}$ Interestingly, the term lecturer has not been included yet in Indonesian Dictionary until 1966. ${ }^{12}$

The term lecturer is firstly being put in Indonesian dictionary in 1982 . Here, the term Lecturer is given meaning or definition as teacher of higher education. ${ }^{13}$ The encyclopaedia of education in 1982 also mentions lecturer as teaching staff in higher education. ${ }^{14}$ The term

${ }^{9}$ Kuntowijoyo, Metodologi Sejarah (Yogyakarta: Tiara Wacana,2003), p. 54-58; Kuntowijoyo, Pengantar Ilmu Sejarah (Yogyakarta: Bentang, 2001), p. 14.

${ }^{10} \mathrm{PJ}$. Zoelmurder and S.O Robson, Kamus Jawa Kuna Indonesia, transl. Darusuprapto, Sumantri Suprayitno (Jakarta: Gramedia Pustaka Utama, 1995), p. 321.

${ }^{11}$ HAR Tilaar, 50 Tahun Pendidikan Nasional (Jakarta: Grasindo, 1995), p. 702.

${ }^{12}$ W.J.S. Perwadarminta, Kamus Umum Bahasa Indonesia, $4^{\text {rd }}$ Edition (Jakarta: Balai Pustaka, 1966), p. 323.

${ }^{13}$ W.J.S Poerwadarminta, Kamus Umum Bahasa Indonesia (Jakarta: Balai Pustaka, 1982), p. 258.

${ }^{14}$ Soegarda Poerbakawatja and H.A.H Hardial, Ensiklopedi Pendidikan (Jakarta: Gunung Agung, 1982), p. 83. 
lecturer in Indonesia 'dosen' is actually taken from Dutch language docent. ${ }^{15}$ Although the term lecturer has been mentioned in the dictionary, however, in the Republic Indonesia Regulation No. 22 Year 1985, this term has not been used. Instead, teaching staffs is used. ${ }^{16}$ In addition, the term teaching staffs is also still used in the Ministerial of Religious Affairs Decree No. 23 Year 1988. ${ }^{17}$

The term lecturer in Indonesian Dictionary published in 1982 is finally being used as a formal term within the Act No. 2 Year 1989. In article 27 verse 3 on the Act No. 2 Year 1989 , it explains that lecturer's main obligation is to teach students in the higher education level. Teachers, on the other hand, are responsible for teaching in the level of high and secondary schools. ${ }^{18}$ Therefore, it can be said that the use of lecturer term begins in 1989 but the definition of those terms has not yet been formulated. The definition of lecturer was firstly formulated in the Government Regulation No. 30 Year 1990 article 1 verse 5 on the Higher Education System. It is stated that lecturer is the education staff in higher education that is specifically entitled to teach as their main duty. ${ }^{19}$ The term lecturer, later on, is used in the Presidential Decree No. 11 Year 1977 article 3 on the Establishment of State Institute of Islamic Studies. ${ }^{20}$

The term teacher and lecturer are confined in the Act No. 20 Year 2003. Article 1 verse 6 states that "Educators mean educational personnel who have the qualification to be teachers, lecturers." ${ }^{21}$

The existence of term teacher and lecturer is given emphasize in the late 2005 marked by the enactment of the Act No. 14 Year 2005. This Act is under the title "Teacher and Lecturer". The definition of teacher is firstly formulated in that Act. Article 1 states that teacher is "a professional educators whose main task is to educate, teach, supervise, lead, train, assess, and evaluate learners in the level of basic formal education, elementary, and secondary schools". Meanwhile, the lecturer is defined in detail as "professional educators and scientist

${ }^{15}$ Datje Rahajoekoesoemah, Kamus Belanda-Indonesia (Jakarta: Rineka Cipta, 1991), p. 333.

${ }^{16}$ Government Regulation on the Basic Organization of State Institute for Islamic Studies (The commitee of IAIN Walisongo Memorial Book, Kenangan Dwi Dasawarsa IAIN Walisongo (Semarang: IAIN Walisongo, 1990), p. 246.

${ }^{17}$ Ministerial of Religious Affiars Decree on the Organization and Function of the Empolyers in State Institute for Islamic Studies Walisongo, in The committee of IAIN Walisongo Memorial Book, Kenangan, p. 290.

${ }^{18}$ Editorial Team of Tugu Muda, Undang-Undang Republik Indonesia Nomor 2 tahun 1989, p. 17.

${ }^{19}$ Government of Indonesia, "Peraturan Pemerintah Republik Indonesia Nomor 30 Tahun 1990 tentang Pendidikan Tinggi," in http://luk.staff.ugm.ac.id/atur/PP30-1990 Pendidikan Tinggi. pdf, accessed on January 12, 2017.

${ }^{20}$ Goverment of Indonesia, "Keputusan Presiden RI Nomor 11 Tahun 1997 tentang Pendirian Sekolah Tinggi Agama Islam Negeri”, in http://docplayer. info/ 180040, accessed on January 12, 2017.

${ }^{21}$ Editorial Team of Wacana Intelektual, Guru dan Dosen, p. 56. 
with the main duties of transforming, developing, and disseminating knowledge, technology, and art through education, research, and society development. ${ }^{22}$

Figure 1: the Development of Teacher and Lecturer Term

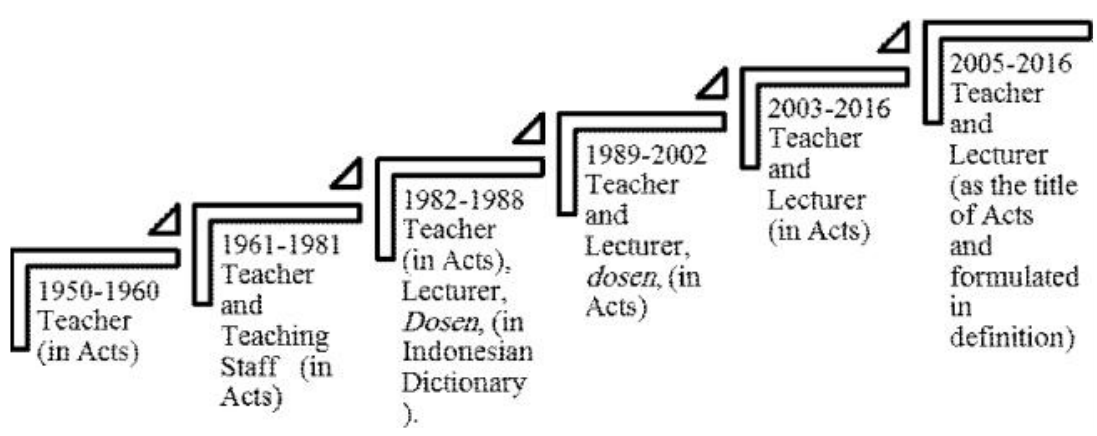

Table.1.

The Development of Teacher and Lecturer Terms within the Indonesian Dictionary and the Acts on Education

\begin{tabular}{|l|c|c|c|l|l|l|}
\hline \multirow{2}{*}{ Year } & \multicolumn{2}{|c|}{ Indonesian Dictionary } & \multicolumn{3}{c|}{ The Acts on Education } \\
\cline { 2 - 7 } & Teacher & $\begin{array}{l}\text { Teaching } \\
\text { Staff }\end{array}$ & Lecturer & \multicolumn{1}{|c|}{ Teacher } & $\begin{array}{c}\text { Teaching } \\
\text { Staff }\end{array}$ & \multicolumn{1}{|c|}{ Lecturer } \\
\hline 1950 & $\checkmark$ & - & - & $\begin{array}{l}\text { Stated as title } \\
\text { of articles }\end{array}$ & - & \\
\hline 1961 & $\checkmark$ & - & - & $\begin{array}{l}\text { Stated as title } \\
\text { of articles }\end{array}$ & $\begin{array}{l}\text { Stated as part } \\
\text { of verses }\end{array}$ & \\
\hline 1982 & $\checkmark$ & - & $\checkmark$ & $\begin{array}{l}\text { Stated as title } \\
\text { of articles }\end{array}$ & $\begin{array}{l}\text { Stated as part } \\
\text { of verses }\end{array}$ & - \\
\hline 1989 & $\checkmark$ & - & $\checkmark$ & $\begin{array}{l}\text { Stated as part } \\
\text { of verses }\end{array}$ & - & $\begin{array}{l}\text { Stated as part } \\
\text { of verses }\end{array}$ \\
\hline 2003 & $\checkmark$ & - & $\begin{array}{l}\text { stated as part } \\
\text { of verses }\end{array}$ & $\begin{array}{l}\text { Stated as part } \\
\text { of verses })\end{array}$ & $\begin{array}{l}\text { Stated as part } \\
\text { of verses }\end{array}$ \\
\hline 2005 & $\checkmark$ & - & $\checkmark$ & $\begin{array}{l}\text { Stated as title } \\
\text { of Acts and } \\
\text { formulated in } \\
\text { definition. }\end{array}$ & & $\begin{array}{l}\text { Stated as title } \\
\text { of Acts and } \\
\text { formulated in } \\
\text { definition. }\end{array}$ \\
\hline
\end{tabular}

\section{Confusion on the Use of the Terms and the Implications}

In this sub-chapter, I will discuss about the confusion of the terms being used in the Acts on National Education System and the education regulations in the Ministerial of Religious Affairs. Those terms are as follows: educational personnel, education staff, teaching staff, and teacher. The discussion will be explained based on the range of time.

${ }^{22}$ Ibid., p. 2. 


\section{The Years of 1950-1988: the Acts Employ the Terms Teacher and Teaching Staff}

The acts of 1950 and 1954 employ the term teacher for kindergarten, elementary, and secondary schools. Meanwhile, the Act No 22 Year 1961 uses the term "teaching staff" for higher education (university, institute, and college). In higher education, there are two familiar terms; permanent and associate teaching staff. ${ }^{23}$ The terms permanent and associate teaching staff are also used in the Ministerial of Religious Affairs Decree No. 23 Year 1988 because the legislation used is still the Act No. 22 Year 1961. ${ }^{24}$

The terms teacher and teaching staff are not interconnected as particular terms. The Acts that mention the term teacher are also different from the ones that use the term teaching staff. The term teacher is included in the Act No 4 Year 1950 juncto the Act No. 12 Year 1954 while the term teaching staff is used in the Act No 12 Year 1961. Their scopes can be illustrated in the following figure:

Figure 2: the Scopes of Teacher and Teaching Staff Term
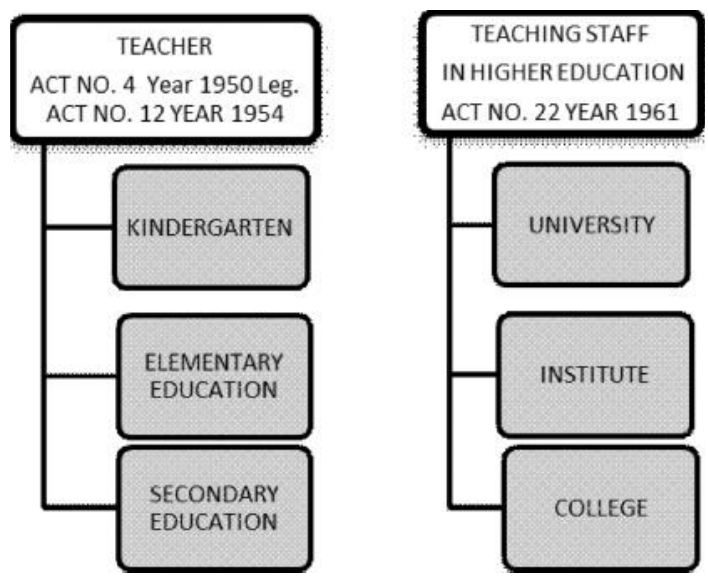

\section{The Years of 1989-2002: the Terms of Educational Personnel, Education Staff, and Teaching Staff}

Since the implementation of the Act No 2 Year 1989, the term educational personnel emerge in the field of Indonesian education. The term educational personnel is also used in the Ministerial of Religious Affairs Decree No. 368 Year 1993 on Madrasah Ibtidaiyah ${ }^{25}$ This

${ }^{23}$ Tilaar, 50 tahun, p. 702.

${ }^{24}$ The commitee of IAIN Walisongo Memorial Book, Kenangan Dwi Dasawarsa, p. 290.

${ }^{25}$ Ministry of Religious Affairs (Indonesia), Himpunan Peraturan Perundang-undangan tentang Pendidikan Nasional (Perguruan Agama Islam) (Jakarta: Dirjen Binbaga Islam, 1999/ 2000), p. 226-229. 
term was unfamiliar in Indonesian dictionaries published in 1982, 1988, 1989, and 1990. They only include the term staff and educate alphabetically separated. ${ }^{26}$

The term educational personnel cover several particular terms. The details are illustrated in Figure 3.

Figure 3: Educational Personnel as a General Term

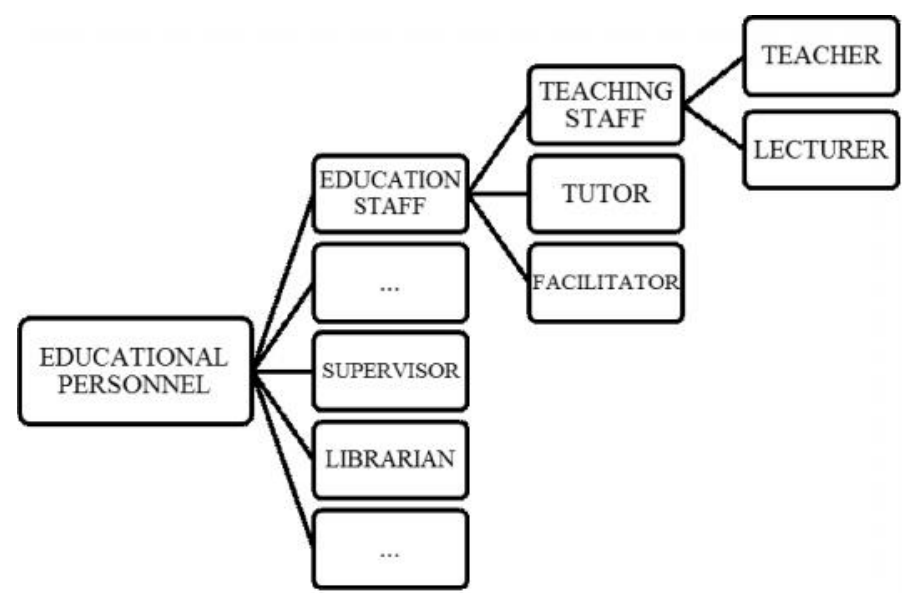

Figure 3 shows that (1) Educational Personnel are society members that devote themselves in administering and provisioning education (Article1 verse 7), (2) Educational personnel is a general term consisting of education staff, manager of unit of education, superintendent, supervisor, researcher, pedagogical developer, librarian, laboratory technician, and other resources technicians (article27 verse 2), (3) Education staff are society members whose duties are guiding, teaching, and training the learners (article1 verse 8), (4) The term education staff includes teaching staff, tutor, and facilitator (article 27 verse 2 and its explanation. (5) The term teaching staff covers the terms teacher and lecturer. The term teacher is applied in education at the level of kindergarten, elementary, and schools. Meanwhile, the term lecturer is used for higher education levels such as academy, polytechnic, college, institute, and university. Those terms can be found in the Act No. 2 Year 1989 Article 12, 13, 14, 15, 16, and $27 .{ }^{27}$

The use of teaching staff to cover the terms teacher and lecturer is theoretically improper. There are two reasons underlying this opinion; (1) The term of education is used gradually and consistently in Indonesia since 1945 to 1989. The Act No. 4 Year 1950, for example, uses the terms education and teaching. However, the Act No. 2 Year 1989 solely applies the title

${ }^{26}$ W.J.S Poerwadarminta, Kamus Umum Bahasa Indonesia (Jakarta: Balai Pustaka, 1982), 1047, Team of Language Research and Development, Kamus Besar Bahasa Indonesia (Jakarta: Balai Pustaka, 1990), p. 927. p. 17.

${ }^{27}$ Editorial Team of Tugu Muda, Undang-Undang Republik Indonesia Nomor 2 tahun 1989, 
"National Education System", not "National Teaching System". ${ }^{28}$ Therefore, the appropriate general term for teacher and lecturer is "education staff" instead of "teaching staff". (2) The term education covers aspects of attitude, knowledge, and skills while the term teaching solely orients to the aspect of knowledge. Teaching is part of education, not in reverse. ${ }^{29}$ Thus, the appropriate term for teacher and lecturer is education staff, not teaching staff. Teacher and lecturer represent a person with attitude, knowledge, and skills. (3) The use of the term teaching staff reduces their ideal roles in education realm. Teacher and lecturer represent three areas (attitude, knowledge, and skills), but, due to the term, it is reduced into one area; knowledge.

The confusion of the ways the terms educational personnel, education staff, and teaching staff being used does not only occur in the Acts but also in the subordinate regulations. One example is found in the formulation of articles in the government regulation No. 38 Year 1992 on Educational Personnel. Article 1 verse 2 states that education staff is educational personnel whose duties are guiding, teaching, and/or training the learners. ${ }^{30}$ Whereas article 1 verse 4 states that "teaching staff is education staffing whose main duty is teaching the learners. ${ }^{31}$

The formulation of article 1 verse 2 is theoretically understandable and raises no issue because the position of education staff is part of educational personnel. However, the formulation of article1 verse 4 is problematic because of the following reasons; (1) Teaching staff should play the role in transforming attitude, knowledge, and skills but their main duties is only transforming knowledge.(2) learners should acquire the transformation of attitude, knowledge, and skills but they only attain knowledge.

\section{The Years of 2003-2005: The Use of the Terms Educator and Educational Personnel}

There are actually efforts in addressing the issue of the confusion for the terms educational personnel, education staff, and teaching staff within the Act No 2 Year 1989 by the revised version introduced in the Act No. 20 Year 2003. The revision can be found in the following illustration.

${ }^{28}$ Muh Saerozi, 'Religious and Moral Education a Historical Study on the Terms and Philosopical Changes in Indonesia 1945-2013', in Journal of Indonesian Islam, Vol. 8, No.1, 2014, p. 45-48.

${ }^{29}$ Ibid., p. 42.

${ }^{30}$ Ministry of Religious Affairs (Indonesia), Himpunan Peraturan Perundang-undangan, p. $46-48$.

${ }^{31}$ Ibid., p. 47. 
Figure 4: the Scope of the Terms of Educator and Educational Personnel

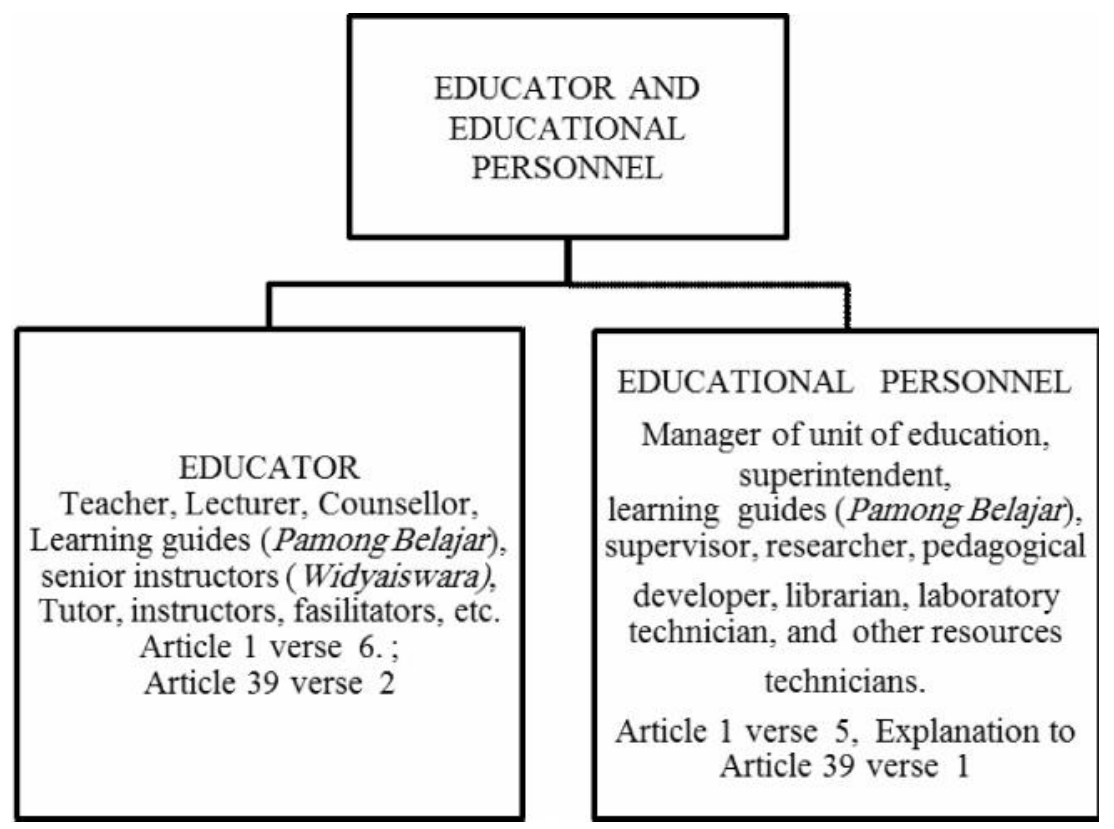

Table 2.

The Concept of Differences between Educator and Educational Personnel in the Act No. 2 Year 1989 and the Act No. 20 Year 2003

\begin{tabular}{|c|c|c|}
\hline Aspect & The Act No. 2 Year 1989 & The Act No. 20 Year 2003 \\
\hline $\begin{array}{l}\text { Chapter } \\
\text { Title }\end{array}$ & $\begin{array}{l}\text { Education Personnel } \\
\text { (Chapter VII) }\end{array}$ & $\begin{array}{l}\text { Educator and Educational Personnel } \\
\text { (Chapter IX) }\end{array}$ \\
\hline $\begin{array}{l}\text { The } \\
\text { description } \\
\text { of } \\
\text { educational } \\
\text { personnel, } \\
\text { duties, and } \\
\text { profession }\end{array}$ & $\begin{array}{l}\text { 1. Educational personnel means members } \\
\text { of an education community devoted } \\
\text { themselves to provision of education. } \\
\text { (Article } 1 \text { verse } 7 \text { ). } \\
\text { 2. Educational personnel have the duty } \\
\text { to carry out teaching, training, } \\
\text { research, developing, administering, } \\
\text { and or servicing in the field of } \\
\text { education. (Article } 27 \text { verse 1). } \\
\text { 3. Educational personnel consists of } \\
\text { education staff, manager of unit of } \\
\text { education, superintendent, supervisor, } \\
\text { researcher, pedagogical developer, } \\
\text { librarian, laboratory technician, and } \\
\text { other resources technicians. (article } \\
27 \text { verse } 2 \text { ) } \\
\text { 4. Administrators of educational units } \\
\text { consist of school principle, director, } \\
\text { dean, and rector. (The explanation } \\
\text { of article } 27 \text { verse 2). }\end{array}$ & $\begin{array}{l}\text { 1. Educational personnel means members } \\
\text { of an education community devoted } \\
\text { themselves to education and are } \\
\text { appointed to support in the provision } \\
\text { of education. (Article } 1 \text { verse5). } \\
\text { 2. Educational personnel have the duty to } \\
\text { carry out administration, organization, } \\
\text { development, monitoring, and technical } \\
\text { service to support education processes } \\
\text { in a unit of education. (Article } 39 \\
\text { verse 1). } \\
\text { 3. Educational personnel consists of manager } \\
\text { of unit of education, superintendent, } \\
\text { learning guides (Pamong Belajar), } \\
\text { supervisor, researcher, pedagogical } \\
\text { developer, librarian, laboratory } \\
\text { technician, and other resources } \\
\text { technicians. (The explanation of } \\
\text { Article } 39 \text { verse 1). }\end{array}$ \\
\hline
\end{tabular}




\begin{tabular}{|c|c|c|}
\hline $\begin{array}{l}\text { The } \\
\text { definition of } \\
\text { education } \\
\text { staff/ } \\
\text { educator, } \\
\text { duties, and } \\
\text { profession. }\end{array}$ & $\begin{array}{l}\text { 5. Education staff means members of an } \\
\text { education community whose duties } \\
\text { are guiding, teaching, and or training } \\
\text { the learners. (Article } 1 \text { verse8). } \\
\text { 6. Teaching staff belongs to education } \\
\text { staff that are particularly offered to } \\
\text { have main duties of teaching. They } \\
\text { are called teacher in the level of } \\
\text { elementary and secondary school, } \\
\text { and lecturer in the higher education } \\
\text { (article } 27 \text { verse } 2 \text { ) } \\
\text { 7. Education staff includes tutor and } \\
\text { facilitator (the explanation of article } \\
27 \text { verse 2). }\end{array}$ & $\begin{array}{l}\text { 4. Educators mean educational personnel } \\
\text { who have the qualification to be teachers, } \\
\text { lecturers, counsellors, learning guides } \\
\text { (Pamong Belajar), senior instructors } \\
\text { (Widyaiswara ), tutors, instructors, } \\
\text { facilitators, and other titles in accordance } \\
\text { with their specialization, and who parti- } \\
\text { cipate in the provision of education. } \\
\text { (Article1 verse 6). } \\
\text { 5. Educators are professional, who have } \\
\text { the duty to plan and implement learning } \\
\text { processes, to assess education outcomes, } \\
\text { to carry out counselling and training, } \\
\text { and to conduct research and community } \\
\text { service, especially for higher education } \\
\text { institution personnel. (Article } 39 \text { verse 2). }\end{array}$ \\
\hline Conclusion & $\begin{array}{l}\text { 1. Education staffs are part of educational } \\
\text { personnel (based on Article } 1 \text { section } 7 \text { ). } \\
\text { 2. Educational personnel are a member } \\
\text { of society that devotes them in } \\
\text { administering education. } \\
\text { 3. Education staff inVolves teaching } \\
\text { staff, tutor, and facilitator. } \\
\text { 4. Teaching staff belongs to education } \\
\text { staff. } \\
\text { 5. Teaching staff consists of teacher and } \\
\text { lecturer. Teacher is for elementary } \\
\text { and secondary schools. Meanwhile, } \\
\text { lecturer is for higher education. }\end{array}$ & $\begin{array}{l}\text { 1. Educator is not a part of educational } \\
\text { personnel. (Based on article } 1 \text { section 5). } \\
\text { 2. Educational personnel is offered to } \\
\text { support in provision of education } \\
\text { 3. Educator consists of teachers, lecturers, } \\
\text { counsellors, learning guides (Pamong } \\
\text { Belajar), senior instructors (widyaiswara), } \\
\text { tutors, instructors, facilitators, and } \\
\text { other titles in accordance with their } \\
\text { specialization, and who participate in } \\
\text { the provision of education. } \\
\text { 4. Teacher and lecturer are called educator, } \\
\text { not teaching staff. }\end{array}$ \\
\hline
\end{tabular}

From the table 2 above, it is clear that there are different concepts between the terms educators and educational personnel used in the Act No. 2 Year 1989 and those used in the Act No. 20 Year 2003. The difference can be comprehended as in (1) The Act No. 20 Year 2003 tries to separate the term education staff from the term educational personnel. The term education staffs, formerly a part of educational personnel in the Act No. 2 Year 1989, is confirmed by the Act N0. 20 Year 2003 as not part of it, but stands independently. (2) The term education staff in the Act No. 2 Year 1989 is also altered into the term of educator. Thus, the term "education staff" in the existing articles is altered into "educator" and "educational personnel". (3) The separation of the term educator from educational personnel eliminates the confusion because the duties of educator are theoretically different from educational personnel. Educator's main duty is teaching whereas educational staffs support educator performance in managing administration, inspecting, and administering educational structure and infrastructure. (4) The term teaching staff that formerly functioned as general term to cover teacher and lecturer is diminished since the enactment of the Act No. 20 Year 2003. Teacher and lecturer do not belong to teaching staff any longer but to educator. 
Although the confusion articles in the Act No. 2 Year 1989 have been revised in the Act No 20 Year 2003, the latest Act on education still maintains several inconsistent issues of inputting the term of educator and educational personnel. The inconsistency can be assumed as in; (1) Article 1 verse 6 states that "educator is educational personnel..." The sentence presumes that educator is part of educational personnel. Meanwhile, Article 39 verse 1 states that the duty of educational personnel is different from that of educator. The main duty of educator orients to learning while the duty of educational personnel is to support educator performance in managing administration, supervising, and administering education structure and infrastructure. The duty description of educational personnel is also clearly confirmed in Article 1 verse 5. It said that “...offer to support in the provision of education". (2) Article 1 verse 6 states that "educator is educational personnel..." while Article 39 verse 2 states that Educators are professional, who have the duty to plan and implement learning processes, etc.

The confusion also occurs in other section. For example, in The Act No. 20 Year 2003, learning guides is categorized as both educator and educational personnel. It means learning guides has double categories. These categories can be read in both article 1 verse 6 and the explanation of article $39 .{ }^{32}$ On the other hand, learning guide is considered as educator because the main duty is learning. ${ }^{33}$

The confusing definitions in the Act No. 20 Year 2003 cause the confusing in other regulations which use this act as guidelines. For example, The Ministerial of Religious Affairs Decree No. 394 Year 2003 categorizes lecturer and administrative staff as educational personnel. ${ }^{34}$ However, the Act No. 20 Year 2003 article 39 verses 1 and 2 categorize them differently. The Government Regulation No. 19 Year 2005 also categorizes education staff and educational personnel differently. Educators are not categorizes as part of the educational personnel. ${ }^{35}$

\section{The Years of 2005-2016: The Use of Term Educator for Teacher and Lecturer}

The Act No. 20 Year 2003 article 1 verse 6 states that term educator consists of teacher,

\footnotetext{
${ }^{32}$ The doble categories for the learning guides is not mistyping. It is demonstrated by the several documents showing similar results, including online documents from the Ministery of Religious Affairs. See http://pendis. kemenag.go.id/file/dokumen/ uuno20 th2003ttgsisdiknas. pdf, accessed on January 12, 2017. Editorial Team of Wacana Intelektual, Guru dan Dosen, p. 56, 103. Hasbullah, Dasar-dasar Ilmu Pendidikan (Jakarta: Raja Grasindo, 2012), p. 305, 348.

${ }^{33}$ The regulation of the Minister of Administrative and Bereaucratic Reform No. 15 Year 2010 on the Academic function Career for Learning guides and the credit points. (http://disdik.tarakan kota.go.id/wp-content/uploads/2013/11/PERMENPAN2010_015.pdf, accessed on January 12, 2017.

34“"The Decree of Ministry of Religious Affairs on the Guidelines Establishing the Religious Higher Education," in http://e-dokumen. kemenag.go. id/files/HvhWEYz81341207641. pdf, accessed on January 12, 2017.

${ }^{35}$ The Government Regulation on the National Education System, Amandemen Standar Nasional Pendidikan (Jakarta: Sinar Grafika, 2013), p. 75-82.
} 
lecturer, counsellor, learning guides, senior instructor, tutor, instructor, facilitator, and other terms within its specification. This Act does not explain, though, the definition of each profession above.

In December $25^{\text {th }}$ of 2005, the Act No.14 Year 2005 under the title of The Act of Teacher and Lecturer has been issued. It is this Act where the description of teacher and lecturer is firstly stated and explained. Article 1 verse 1 states that teacher is a professional educator with the main duties of educating, teaching, supervising, guiding, training, assessing, and evaluating the Learners in basic formal education, elementary and secondary ones. Meanwhile, Article 1 verse 2 mentions that lecturer is a professional educator whose main duties of transforming, developing, and disseminating knowledge, technology, and art through education, research, and society development program. ${ }^{36}$

Based on this definition, it can be stated that: (1) educator is a general term covering several particular terms such as teacher and lecturer. As previously explained, the term teacher is explicitly stated in the Act No. 4 Year 1950 while the term lecturer has been introduced and being familiarized trough the Act No. 2 Year 1989. (2) Teacher and lecturer are forms of educator profession. The Acts recognize other professions of educator such as counsellor, learning organizer, senior lecturer, tutor, instructor, facilitator, and other terms within the specification. (3) Teacher and lecturer are educator which means that their roles are not limited to or exactly the same as the role of "teacher". Teacher as educator plays the role not only in transforming knowledge but also attitude and skills in integrative way. (4) Teacher owns position as professional staff in the level of basic formal education, elementary and secondary schools. (5) Lecturer holds position as professional staff in higher education. (6) the Act No. 14 Year 2005 does not categorizes teacher and lecturer as part of educational personnel. However, teacher and lecturer have their own category.

Although the definition of teacher and lecturer has been defined in the Act No. 14 Year 2005, it requires to be scrutinized due to the reference of the Act No. 20 Year 2003. The Act still consists of article formulation inconsistency based on the definition above. So, it requires an alternative solution in order to revise the article formulation on educator and educational personnel.

\section{Alternative of Formulation}

Considering the formulation inconsistency of inter-articles on educator and educational personnel, revision is clearly needed. The possible model for revision is by combining the formulation of article in the Act No. 2 Year 1989 and the Act No. 20 Year 2003.The alternative revision is explained in the following figure:

${ }^{36}$ Editorial Team of Wacana Intelektual, Guru dan Dosen, p. 2. 
The Title of Article

The title of articles better use the term "educational personnel" and its particular terms: "Educator" and "Educational Support Personnel".

Figure 5: the Proposed Title of Article

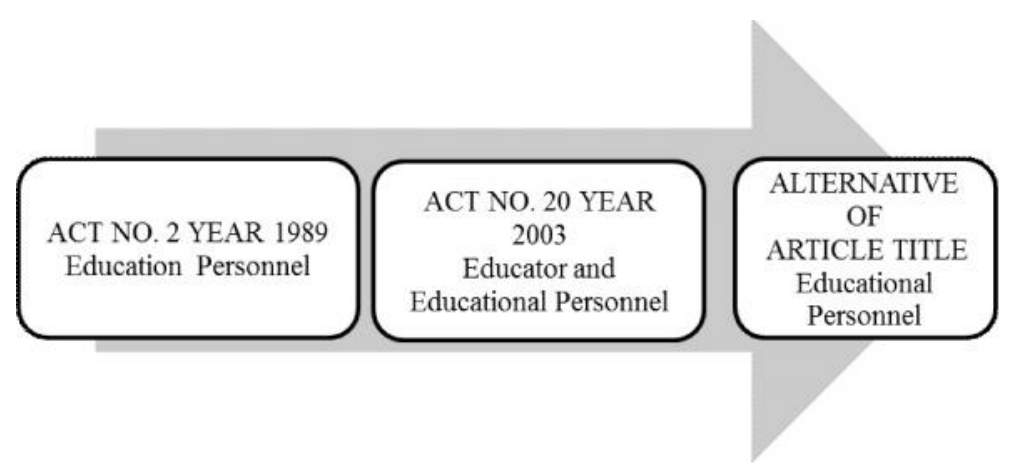

Figure 6.The Scope of Educational Personnel

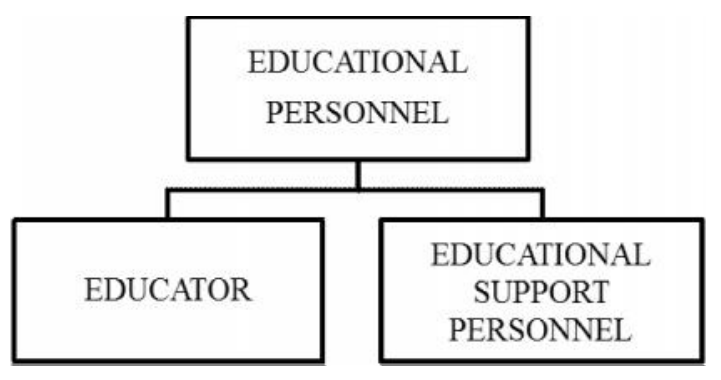

The term educational personnel becomes the title of article due to several reasons as follows; (1) Indonesian dictionary published in 2007 describes educational personnel as "society members that devote themselves to provision of education based on expertise and provide supervision, teaching, research, organizer, or education administrator". ${ }^{37}$

The definition of educational personnel in the dictionary is affected by its definition in the Act of Education of 1989. The content of the definition indicates that the duty of educational personnel is provisioning or administering education, not merely support education administration as stated in the Act of Education Year 2003.(2) There are two duties for educational personnel. First is the main duty that is managing learning process. This duty is performed by educator. Second duty is an additional duty for support of education process conducted by other professionals including administrator, laboratory assistant, librarian, inspector, researcher, and learning source technician. Hence, educational personnel as a general term include two particular terms: educator and educational support personnel.

${ }^{37}$ National Education Department, Kamus Besar Bahasa Indoenesia, $3^{\text {rd }}$ Edition (Jakarta: Balai Pustaka, 2007), p. 1171. 
MIQOT Vol. XLI No. 2 Juli-Desember 2017

\section{The Description of Educational Personnel}

The definition of educational personnel can be re-formulated by proportionally combining the formulations in the Article No. 2 Year 1989 with that in the Act No. 20 Year 2003.

Table 3.

The Proposed Article on Educational Personnel

\begin{tabular}{|c|c|c|c|}
\hline Aspect & Act No. 2 Year1989 & $\begin{array}{c}\text { Act No. } 20 \text { Year } \\
2003\end{array}$ & Alternatif of Article \\
\hline DEFINITION & $\begin{array}{l}\text { Educational personnel } \\
\text { means members of an } \\
\text { education community } \\
\text { devoted themselves to } \\
\text { provision of education. } \\
\text { (Article } 1 \text { verse } 7 \text { ). }\end{array}$ & $\begin{array}{l}\text { Educational personnel } \\
\text { means members of an } \\
\text { education community } \\
\text { devoted themselves } \\
\text { to education and are } \\
\text { appointed to support } \\
\text { in the provision of } \\
\text { education. (Article } 1 \\
\text { verse } 5 \text { ). }\end{array}$ & $\begin{array}{l}\text { Educational personnel means } \\
\text { members of an education } \\
\text { community devoted } \\
\text { themselves to provision of } \\
\text { education. }\end{array}$ \\
\hline DUTY & $\begin{array}{l}\text { Educational personnel } \\
\text { have the duty to carry } \\
\text { out teaching, training, } \\
\text { research, developing, } \\
\text { administering, and/ or } \\
\text { servicing in the field of } \\
\text { education. (article } 27 \\
\text { verse 1). }\end{array}$ & $\begin{array}{l}\text { Educational personnel } \\
\text { have the duty to carry } \\
\text { out administration, } \\
\text { organization, } \\
\text { development, } \\
\text { monitoring, and } \\
\text { technical service to } \\
\text { support education } \\
\text { processes in a unit of } \\
\text { education. (Article } \\
39 \text { verse 1). }\end{array}$ & $\begin{array}{l}\text { Educational personnel have } \\
\text { the duty to carry out plan and } \\
\text { implement learning processes, } \\
\text { to assess education outcomes, } \\
\text { to carry out counseling and } \\
\text { training, administration, } \\
\text { organization, development, } \\
\text { monitoring, and technical } \\
\text { service to support education } \\
\text { processes in a unit of } \\
\text { education. }\end{array}$ \\
\hline PROFESSION & $\begin{array}{l}\text { Educational personnel } \\
\text { consists of education } \\
\text { staff, manager of unit } \\
\text { of education, super- } \\
\text { intendent, supervisor, } \\
\text { researcher, pedagogical } \\
\text { developer, librarian, } \\
\text { laboratory technician, } \\
\text { and other resources } \\
\text { technicians. (article } 27 \\
\text { verse 2) } \\
\text { Manager of unit of } \\
\text { education consists of } \\
\text { school principle, director, } \\
\text { dean, and rector. (The } \\
\text { explanation of article } \\
27 \text { verse } 2 \text { ). }\end{array}$ & $\begin{array}{l}\text { Educational personnel } \\
\text { consists of manager } \\
\text { of unit of education, } \\
\text { superintendent, } \\
\text { learning guides } \\
\text { (pamong belajar), } \\
\text { supervisor, researcher, } \\
\text { pedagogical developer, } \\
\text { librarian, laboratory } \\
\text { technician, and other } \\
\text { resources technicians. } \\
\text { (The explanation of } \\
\text { Article } 39 \text { verse 1). }\end{array}$ & $\begin{array}{l}\text { Educational personnel consists } \\
\text { of educators, manager of unit } \\
\text { of education, superintendent, } \\
\text { supervisor, researcher, peda- } \\
\text { gogical developer, librarian, } \\
\text { laboratory technician, and } \\
\text { other resources technicians. } \\
\text { (explanation of article: } \\
\text { Manager of unit of education } \\
\text { consists of school principle, } \\
\text { director, dean, and rector). }\end{array}$ \\
\hline
\end{tabular}




\section{The Description of Educator}

The proposed definition of educator tends to follow the formulation in the Act No. 20 Year 2003 instead of the Act No. 2 Year 1989. Educator is categorized as part of educational personnel. Therefore, as will be explained in the table 4 below, there is a need for re-formulating the definition of the educator.

Table 4.

The Proposed Article on Educator

\begin{tabular}{|c|c|c|c|}
\hline Aspect & Act No. 2 Year 1989 & Act No. 20 Year 2003 & Alternatif Article \\
\hline DEFINITION & $\begin{array}{l}\text { 1. Education staff means members } \\
\text { of an education community } \\
\text { whose duties are guiding, } \\
\text { teaching, and or training the } \\
\text { learning participants. (Article } 1 \\
\text { verse 8). } \\
\text { 2. Teaching staffs belong to edu- } \\
\text { cation staffs that are particularly } \\
\text { offered to have main duties of } \\
\text { teaching. They are called teacher } \\
\text { in the level of elementary and } \\
\text { secondary school, and lecturer } \\
\text { in the higher education (article } \\
27 \text { verse3) } \\
\text { 3. Education staff include of tutor } \\
\text { and facilitator (the explanation } \\
\text { of article } 27 \text { verse 2). }\end{array}$ & $\begin{array}{l}\text { Educators mean edu- } \\
\text { cational personnel who } \\
\text { have the qualification to } \\
\text { be teachers, lecturers, } \\
\text { counsellors, learning } \\
\text { guides (Pamong Belajar), } \\
\text { senior instructors } \\
\text { (widyaiswara), tutors, } \\
\text { instructors, facilitators, } \\
\text { and other titles in } \\
\text { accordance with their } \\
\text { specialization, and who } \\
\text { participate in the } \\
\text { provision of education. } \\
\text { (Article1 verse 6). }\end{array}$ & $\begin{array}{l}\text { Educators mean edu- } \\
\text { cational personnel } \\
\text { who have the } \\
\text { qualification to be } \\
\text { teachers, lecturers, } \\
\text { counsellors, } \\
\text { learning guides, } \\
\text { senior instructors, } \\
\text { tutors, instructors, } \\
\text { facilitators, and } \\
\text { other titles in } \\
\text { accordance with } \\
\text { their specialization, } \\
\text { and who participate } \\
\text { in the provision of } \\
\text { education. }\end{array}$ \\
\hline DUTY & $\begin{array}{l}\text { Education staff means members } \\
\text { of an education community } \\
\text { whose duties are guiding, } \\
\text { teaching, and or training the } \\
\text { learning participants. (Article } 1 \\
\text { verse 8). }\end{array}$ & $\begin{array}{l}\text { Educators are } \\
\text { professional, who have } \\
\text { the duty to plan and } \\
\text { implement learning } \\
\text { processes, to assess } \\
\text { education outcomes, to } \\
\text { carry out counselling } \\
\text { and training, and to } \\
\text { conduct research and } \\
\text { community service, } \\
\text { especially for higher } \\
\text { education institution } \\
\text { personnel. (Article } 39 \\
\text { verse 2). }\end{array}$ & $\begin{array}{l}\text { Educators are } \\
\text { professional, who } \\
\text { have the duty to plan } \\
\text { and implement } \\
\text { learning processes, } \\
\text { to assess education } \\
\text { outcomes, to carry } \\
\text { out counselling and } \\
\text { training, and to } \\
\text { conduct research } \\
\text { and community } \\
\text { service, especially } \\
\text { for higher education } \\
\text { institution personnel. }\end{array}$ \\
\hline
\end{tabular}

\section{The Description of Educational Support Personnel}

The definition of Educational Support Personnel is re-formulated by borrowing several terms and explanation from the Act No. 2 Year 1989 and the Act No. 20 Year 2003. 
Table 5.

The Proposed Article on Educational Support Personnel

\begin{tabular}{|c|c|c|}
\hline Definition & Duty & Profession \\
\hline $\begin{array}{l}\text { Educationnal Support } \\
\text { Personnel means } \\
\text { members of an education } \\
\text { community devoted } \\
\text { themselves to support } \\
\text { and participate in the } \\
\text { provision of education. }\end{array}$ & $\begin{array}{l}\text { Educational Support Personnel } \\
\text { have the duty to carry out adminis- } \\
\text { tration, organization, develop- } \\
\text { ment, monitoring, and technical } \\
\text { service to support education } \\
\text { processes in a unit of education. }\end{array}$ & $\begin{array}{l}\text { Educational Support Personnel } \\
\text { consists of manager of unit of } \\
\text { education, superintendent, } \\
\text { supervisor, researcher, peda- } \\
\text { Ogogical developer, librarian, } \\
\text { laboratory technician, and } \\
\text { other resources technicians. }\end{array}$ \\
\hline
\end{tabular}

The definition of Educational Support Personnel is almost similar to the definition in Article 1 verse 5 and Article 39 verse 1 of the Act No. 20 Year 2003. The difference is on the absence of learning guides. Therefore, the term Educational Support Personnel is more accurately used in Acts because this term relates to its scope of responsibility to support educational administration.

Figure7. The scope of responsibility of educator and educational assistive-staff.

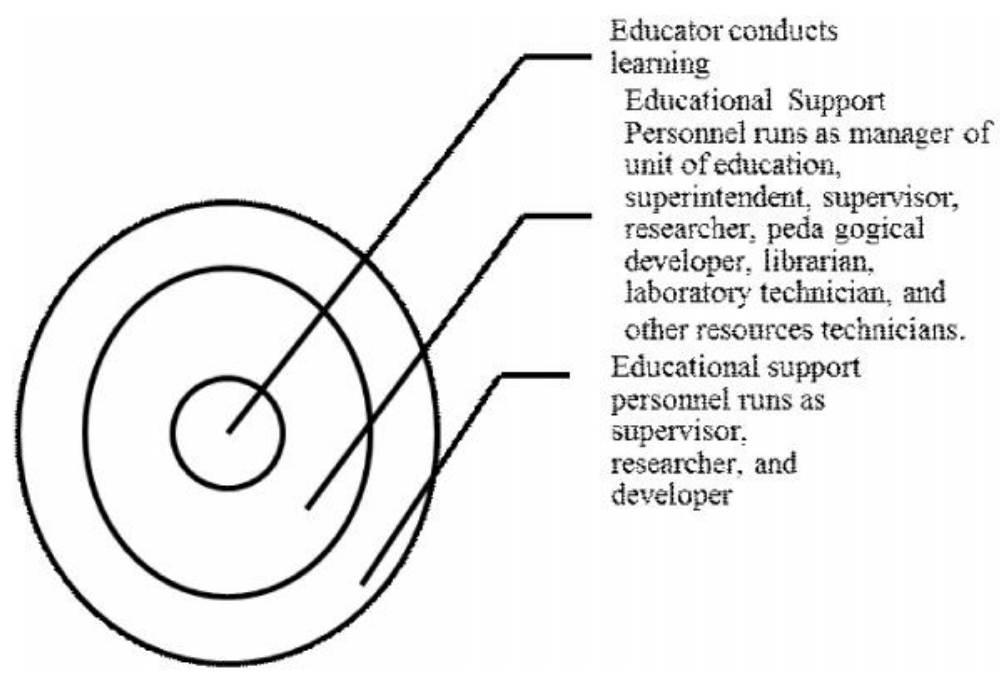

\section{Reflection}

From some problems and confusions exposed previously, there are several points which can be concluded as reflections. Theoretically, policy on education should be formulated and developed through several stages. One of the most important step before the enactment of a legislation is indeed the formulation. Almost all policy analysis experts agree that the formulation of a policy is the most important and the most crucial steps in the stages of a development of policy. ${ }^{38}$ This paper shows that there are problems in the formulation of

${ }^{38}$ H.M. Hasbullah, Kebijakan Pendidikan (Jakarta: Rajawali, 2015), p. 81. 
policy on education in Indonesia and this includes Act number 20 Year 2003 as well as the existing Acts prior it. The confusion on the Act of National Education System influences other regulations which use the Act as guidelines and also other education regulation in the Ministry of Religious Affairs.

The severity of the problems within it is indicated mostly by the vagueness in the diction and redaction explained as follows:

\section{From the Diction Aspect}

The problems in the diction aspect can be best reviewed from two things: First is the categorization in teachers in schools and lecturers in university or higher educational institution. Act number 2 year 1989 categorizes school teachers and lecturers as teaching staffs. Meanwhile, Act number 20 year 2003 and Act number 14 year 2005 categorize them as educators. Categorizing lecturers and school teachers as 'teaching staffs' is 'heritage' from Act number 4 year 1950 junto Act number 4 year 1954 and Act number 22 Year 1961. Second, The term change from "teaching staff" to "educator" makes both the school teachers and lecturers being referred to as educators in the Act number 20 year 2003. The change of the term is influenced by the dominant diction in the Act number 2 Year 1989. This change has significant theoretical consequence in the context of National education policy.

The changing process from "teaching staff" to "educator" is very more relevant with the substance of Madrasah and Islamic Higher Education. Ahmad Tafsir argues that Islamic education should cover three human aspects. They are: physical entities, ratio and soul. The truth that is internalized in the education process is not merely the logic-empirical and abstract-empirical, but covers further to the abstract super logic. The educational process is not only to actualize the potential ratio and sense, but also covers the potential feeling. The orientation of education is not only on the research and logical thinking, but also how to train the learners to believe the supra logic. This will strengthen their inner experiences. ${ }^{39}$ Such a process, according to Abudin Nata, should be started from teacher as the model in several competencies, like pedagogical competency, personal competency, professional competency, and social competency. ${ }^{40}$

\section{Crucial from Redaction Aspect}

The severity and complexity of the problem in this issue also can be seen from the problematic redaction. First problem is the vague definition of teaching staff within Act number 2 years 1989. The act states that the teachings staffs are the educator who is specifically assigned with teaching as the main function. Here, there is confusion on the scope and definition of

\footnotetext{
${ }^{39} \mathrm{Ahmad}$ Tafsir, Ilmu Pendidikan dalam Perspektif Islam (Jakarta: Rosyada, 2014), p. 33.

${ }^{40}$ Abudin Nata, Ilmu Pendidikan Islam (Jakarta: Kencana, 2010), p. 165-170.
} 
the task of educating and teaching. Second problem is the vague definition of educational personnel in the Act number 20 Year 2003. On the one hand, using the definition, educator is excluded from the definition educational personnel. On the other hand, they are still categorized as educational personnel's. I believe that here is where the confusion happens.

This confusion in diction and redaction has implications to other policies in the stage below it. As already known, policy on education has hierarchy and the higher level will affect the lower level. ${ }^{41}$

Figure 8. The Hierarchy of National Policy on Education

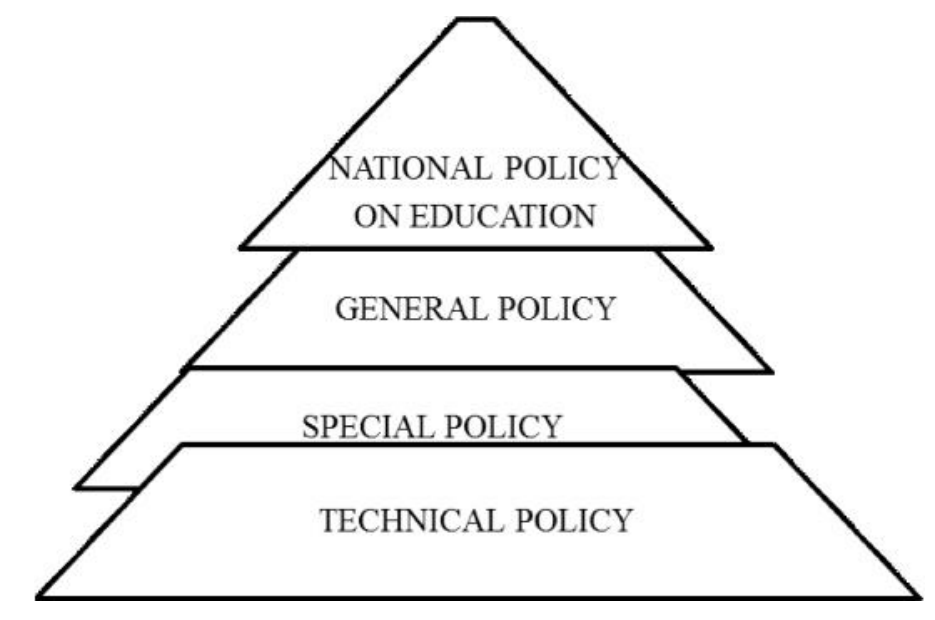

History records that the confusion in diction and redaction does affect the implementation processes. For example, when the Supreme Court granted a request for judicial review of the legislation, the implementation of the policy should be changed. Sudden changes will not only affect the normative aspect, but also practical aspect. The happening has occurred in 2012. Constitutional Court Hearing at that time has granted the suit to cancel the International Standard School and International Standard school pilot project in Indonesia. However, these programs have already lasted for two years and even almost all senior high schools are encouraged to establish these programs. The effects of cancelation impact not only in the law area, but also spread to the institution aspect, procedure, learning process, funding, and even administration like sign board, headings and stamps. ${ }^{42}$

\section{Conclusion}

A national policy on education, moreover the education policy in the ministry of religious

${ }^{41}$ M. Hasbullah, Kebijakan, p. 47-51.

${ }^{42}$ Fajar Laksono, et. al., 'Implikasi Dan Implementasi Putusan Mahkamah Konstitusi Nomor 5/Puu-X/2012 Tentang Sekolah Bertaraf Internasional (SBI)/Rintisan Sekolah Bertaraf Internasional (RSBI)," in http://www. mahkamahkonstitusi.go.id/public/ content/infoumum/ penelitian/ pdf/Implikasi\%20Putusan\%20RSBI. pdf, accessed on January 12, 2017. 
affairs, is ideally supposed to be promoting betterment in the realm of implementation. The policy has many functions including the standardization and provision of explanations on how the practical level should be implemented. Unfortunately, this ideal has not yet been found in the national policy on educational policy in the ministry of religious affairs. As a matter of fact, as the paper has explored, the Acts on education tend to be problematic, especially about educators. This problem also exists in other regulations in the Ministry of Religious Affairs. One of the biggest problems is the ways in which the terms are used, changed and explained. To give illustration, Acts on education in Indonesia have been using improper terms and explanation in stating education staff, teaching staff, educational personnel, and educator. The term teaching staffs in the Act No 22 Year 1961 is improper due to the fact that the previous act has used the term education. Moreover, it has quite substantive implications as the meaning of the term educator, the previously used one, covered the term teaching staff. And, educator is obliged to transform attitude, knowledge, and skills while the teaching staff's main task is only transforming the knowledge. Similarly, the term teaching staff in Article 27 verse 2 the Act No 2 Year 1989 is also not proper because the term is used to represent teacher and lecturer. Meanwhile, the duty of teacher and lecturer is educating, not only teaching. Thus, teacher and lecturer better categorized as educator instead of being narrowed to a specific term teaching staff. The usage of the term teaching staff in the Act for teacher and lecturer actually reduces their ideal roles as education staff. Interestingly, the paper also shows that the confusion continues even though there are several efforts to address the issue of inconsistency. Even though the term "education staff" in the Act No. 2 Year 1989 is revised into "educator" in the Act No. 20 Year 2003 and the term "teaching staff" is also revised into "educator", the articles on educators in the Act No. 20 Year 2003 remain the issues of inconsistency. The problems exist in Article 1 verse 5 and 6, and Article 39 verse1. Admittedly, Article 1 verse 6 has included educator in the proper position as part of the educational personnel, but Article 39 verse 1 keeps stating that educational personnel have specific responsibilities different from educator. Article 1 verse 5 also keeps stating the positions of educational personnel as support with main duty of administering education. This inconsistency also occurs in the Ministerial of Religious Affairs No. 394 Year 2003.The term educator is used in the Act No. 14 Year 2005 to represent the terms teacher and lecturer since The Act of Teacher and Lecturer refers to the Act No. 20 Year 2003. However, there are still issues of inconsistency in the article formulation. Therefore, the revision in the formulation of inconsistent articles is required. One of the possible revisions for the title of chapters and articles on "educator and educational personnel" are as proposed; the title of chapter is revised into "educational personnel". In sum, the Acts on education in Indonesia are problematic and therefore the revisions are important in order to make the Acts more relevant in its role to promote betterment of education in the Ministry of Religious Affairs and National Education in general. 
MIQOT Vol. XLI No. 2 Juli-Desember 2017

\section{References}

Djohar. "Analisis Undang-undang Sisdiknas Ditinjau dari Segi Praksis Pendidikan dan Anggaran Pendidikan," in Jurnal Konstitusi. Vol. 3, No. 1, 2006.

Editorial Team of Sinar Grafika. Amandemen Standar Nasional Pendidikan. Jakarta: Sinar Grafika, 2013.

Editorial Team of Tugu Muda. Undang-undang Republik Indonesia Nomor 2 Tahun 1989: Sistem Pendidikan Nasional. Semarang: Tugu Muda, 1989.

Editorial Team of Wacana Intelektual. Guru dan Dosen \& Sisdiknas. NP: WI Press, 2006.

Goverment of Indonesia. "Keputusan Presiden RI Nomor 11 Tahun 1997 tentang Pendirian Sekolah Tinggi Agama Islam Negeri”, in http://docplayer. info/ 180040-, accessed on January 12, 2017.

Goverment of Indonesia. "Peraturan Menteri Pemberdayaan Aparatur Negara No. 15 Tahun 2010", in http://disdik.tarakankota.go.id/wp-content/uploads/2013/11/ PERMENPAN 2010_015.pdf, accessed on January 12, 2017.

Government of Indonesia. "Peraturan Pemerintah Republik Indonesia Nomor 30 Tahun 1990 Tentang Pendidikan Tinggi”, in http://luk.staff.ugm.ac.id/atur/PP30-1990 Pendidikan Tinggi.pdf, accessed on January 12, 2017.

Government of Indonesia. "Undang-undang Republik Indonesia Nomor 20 Tahun 2003 tentang Sistem Pendidikan Nasional”, in http://pendis.kemenag.go.id/file/dokumen/ uuno20 th 2003 ttgsisdiknas.pdf, accessed on January 12, 2017.

Hasbullah, M. Dasar-dasar Ilmu Pendidikan. Jakarta: Raja Grasindo, 2012.

Hasbullah, M. Kebijakan Pendidikan. Jakarta: Rajawali, 2015.

Himpaudi. "Masalah Dikotomi PAUD \& Dampaknya terhadap Mutu dan Kesejahteraan Pendidik PAUD Non Formal serta Usulan Perubahan Undang-Undang," in https://www.change.org/ p/mahkamah-konstitusi-ubah-undang-undang-sisdiknas-serta-undang-undangguru-dan-dosen-terkait-paud/u/13559697, accessed on December 28, 2016.

Kuntowijoyo. Metodologi Sejarah. Yogyakarta: Tiara Wacana, 2003.

Kuntowijoyo. Pengantar Ilmu Sejarah.Yogyakarta: Bentang, 2001.

Laksono, Fajar, et al. "Implikasi dan Implementasi Putusan Mahkamah Konstitusi Nomor 5/ Puu-X/2012 Tentang Sekolah Bertaraf Internasional (SBI)/RintisanSekolah Bertaraf Internasional (RSBI)," in http://www.mahkamahkonstitusi. co.id/ public/content/ infoumum/penelitian/pdf/Implikasi\%20Putusan\%20RSBI.pdf, accessed on January 12, 2017).

Ministry of Religious Affairs (Indonesia). Himpunan Peraturan Perundang-undangan tentang Pendidikan Nasional: Perguruan Agama Islam. Jakarta: Dirjen Binbaga Islam, 1999/2000.

Nasution, S. Sejarah Pendidikan Indonesia. Jakarta: Bumi Aksara, 1994.

Nata, Abudin Nata. Ilmu Pendidikan Islam. Jakarta: Kencana, 2010. 
Muh. Saerozi: Confusion of Educator Policy in Ministry of Religious Affairs 1945-2016

National Education Department. Kamus Besar Bahasa Indoenesia. $3^{\text {rd }}$ Edition. Jakarta: Balai Pustaka, 2007.

Perbakawatja, Soegarda. Pendidikan dalam Alam Indonesia Merdeka. Jakarta: Gunung Agung, MCMLXX.

Poerbakawatja, Soegarda and H.A.H Hardial. Ensiclopedi Pendidikan. Jakarta: Gunung Agung, 1982.

Poerwadarminta, W.J.S. Kamus Umum Bahasa Indonesia. Jakarta: Balai Pustaka, 1982.

Poerwadarminta, W.J.S. Kamus Umum Bahasa Indonesia.4 ${ }^{\text {rd }}$ Edition. Jakarta: Balai Pustaka, 1966.

Rahajoekoesoemah, Datje. Kamus Belanda-Indonesia. Jakarta: Rineka Cipta, 1991.

Redaksi. 'Pengantar Redaksi,' in Jurnal Konstitusi 3, No. 1, February 2006.

Riyadi, Ali. Politik Pendidikan: Menggugat Birokrasi Pendidikan Nasional. Yogyakarta: ArRuzz Media, 2006.

Saerozi, Muh. "Religious and Moral Education a Historical Study on the Terms and Philosopical Changes in Indonesia 1945-2013," in Journal of Indonesian Islam, Vol 8, No. 1, 2014.

Shohib, Moh. "Mengembalikan Pendidikan sebagai Hak Asasi Manusia," in Jurnal Konstitusi, Vol. 3, No. 1. 2006.

Tafsir, Ahmad. Ilmu Pendidikan dalam Perspektif Islam. Jakarta: Rosyada, 2014.

Team of Language Research and Development. Kamus Besar Bahasa Indonesia. Jakarta: Balai Pustaka, 1990.

The Commitee of IAIN Walisongo Memorial Book. Kenangan Dwi Dasawarsa IAIN Walisongo. Semarang: IAIN Walisongo, 1990.

Tilaar, HAR. 50 Tahun Pendidikan Nasional. Jakarta: Grasindo, 1995.

Zoelmurder, PJ. and S.O Robson. Kamus Jawa Kuna Indonesia, transl. Darusuprapto, Sumantri Suprayitno. Jakarta: Gramedia Pustaka Utama, 1995. 